\title{
Learning English Reading Skill Through E-Learning
}

\author{
Baiatun Nisa \\ Academy of Foreign Language BSI Jakarta \\ Email: nisa_anwar88@gmail.com
}

\begin{abstract}
This study aims at deep-portraying the learning of reading skill at Universitas Terbuka (UT, literally Open University) Indonesia. The research was conducted from March 2014 to February 2015. The approach used in this study is a qualitative approach conducted with ethnographic methods by adopting the method of Spradley. The data collecting techniques being used were observation, interview, and document analysis. Data is analyzed by using techniques such as domain, taxonomy, component, and theme analysis. The result of the analysis shows that the learning system implemented at UT is through the use of the Internet known as elearning or online tutorial is appropriate and involve many means to improve reading skills such as the presence of additional materials (initiation), online discussions, and digital library. The cultural finding which is continuously occuring within the learning process is the emerging new roles of teacher in e-learning based on classes. These roles include: (1) mastering the ICT and having the ability to handle technical problems on the technology; (2) having the ability to interact with students in written form; (3) becoming a motivator; and (3) giving written feedback to students.
\end{abstract}

Keywords: Reading Comprehension, e-Learning, Ethnography

\section{INTRODUCTION}

Traditionally, teaching has been a face to-face experience. The interaction between the teacher and the student (s) and among student participants plays a strong role in shaping the learning experience of those participants.

Distinct from conventional face-to-face learning and also blended-learning (a mix between face-to-face and information technology-based learning), the nature of long distance learning using e-learning platform desires an independent learning process to take place and requires no physical class facility.
What needed is learning facilities in a form of electronic media through internet (world wide web) and learning assistance by the education institution. Students must be able to learn independently through a large scale of different types of communication media which is presented long distancely and facilitated by the school administrator.

Therefore, a web-based distance learning system or e-learning must note the four building blocks: instructional material, learning process, evaluation of learning outcomes, and management (see Diagram 1).

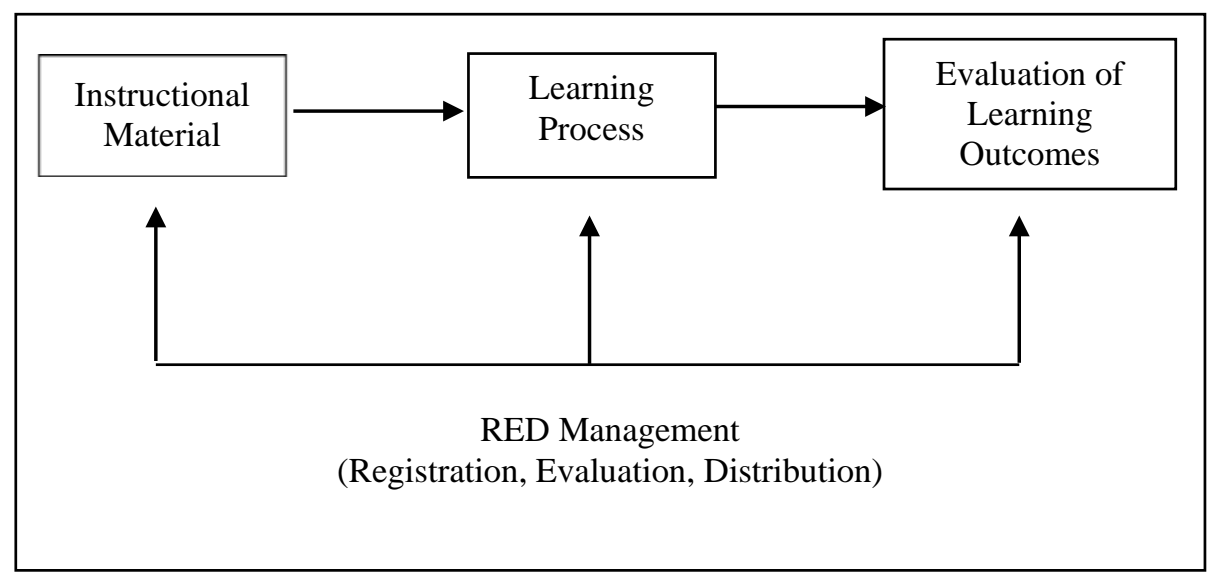

Source: D. Andriani (2003). Management of Distance Learning. Jakarta: SEAMOLEC

Figure 1. Distance Learning System 
According to Andriani (2003: 36)Instructional material of an e-learning based education must be designed in such a way that is able to meet students' needs to learn independently. The kind of instructional material that students can optimally learn independently is one that uses modular system. Even though the instructional material has been developed specifically for independent learning, students still need learning assistance. They still need feedback. It is where tutorial takes part in an elearning system. Tutorial can also support students who have difficulties when learning independently.

Both the material and the process of evaluating the learning outcomes are done by paying close attention to components that are used in developing instructional material. Another crucial matter regarding evaluation material is leakage. Consequently, an e-learning system highly demands a through and well-controlled management system.

\section{Reading Comprehension of a Foreign Language}

Murphy (2005:2) defined reading as a process of understanding message from text that is built by the writer using othographic symbols. It means reading is an activity of capturing information within a text. In addition, Flood and Laap (2001: 350) stated that reading is a thinking process in which the reader becomes active participant. Readers not only literally pay attention to written symbols, but also connect the concepts of both knowledge and pragmatic experiences they already have towards the symbols. While Robeck and Wilson (1974) in Alexander and Heathington (1988: 4) stated that reading is a process of translating new meaning into coginitive and affective system. Thus reading is a communication activity in which a reciprocal relationship between readers and text content occurs. In learning the reading skill, Brown (1994: 64) proposed principles in designing interactive reading by subdividing the teaching techniques into three phases, (1) pre-reading; (2) during-reading; (3) postreading. The following is the description of each phase which also highlights the importance of employing them in developing reading competence.

a. Pre-Reading Activity

According to Williamson (1988: 7-8) pre-reading activity can be done by posing questions both in oral and written forms the students will look for during reading. Or it can also be done by writing students' own experience containing their knowledge about the topic. Pre-reading activity is an activity that can arouse interest and reason to read.

b. During-Reading Activity

During-reading activity is an activity that develops reading skill.The main purpose of duringreading is construct students' reading competency, not only comprehending, capturing, but also building information within the text.

\section{c. Post-Reading Activity}

Post-reading is the last phase in the learning of reading. William (2003: 10) pointed out that this activity is meant to improve students' comprehension and interest towards reading. ${ }^{8}$ This activity can be done by connecting what students have read with their real experience. It can also be done by asking students their opinion about the passage whether they agree or disagree, happy or unhappy, and by giving the reason. The main purpose of post-reading is relating the reading contents with students' everyday activities.

\section{RESEARCH METHOD}

This research is done at the English Study Program, Universitas Terbuka (UT). It was carried out in the 2014/2015 academic year for a whole year from September 2014 to August 2015.The research method of this study is etnographic method which was introduced by James P. Spradley. It applies the data analysis procedures which are: (1) domain analysis; (2) taxonomy analysis; (3) component abalysis; and (4) cultural theme analysis. Data collecting is carried out using observation, interview, and document analysis technique.

The data collection focused on three sources, they are: documents (curriculum and design of learning written by lecturers), informants (teachers and students), and events (the process of learning to read English-based e-learning). Data validity checking is done consists of credibility, transferability, dependability, and conformability.

\section{RESULTS AND DISCUSSION}

The system of learning to read English at UT by using systems based on e-learning turns showed some ease is felt both by teacher and by the students associated with changes in the concept of learning, namely: (1) the lecturer is able to make the learning process in time is not bound, meaning lecturers can make contact with students (who live far away), everywhere and at any time, (2) students can also easily take courses anywhere without limited again on the limits of institutions and countries; (2) students can easily study and discuss with experts in the field that interested him; (4) The lecture materials can even be easily taken in various parts of the world, regardless of the college where students learn. The results showed that the success of elearning supported by the maximum interaction between teacher and students, between students with different educational facilities, among students with other students, and their active learning patterns in the interaction. Then the student activity center, inter-group interaction, administrative support systems, deepening materials, exams, digital libraries, and online materials proven to make 
learning program based on e-learning successfully implemented.

\section{The application of the learning of English reading skill through e-learning}

As explained before, it is imperative for an e-learning based distance learning system to pay attention toits four building blocks: instructional material, learning process, evaluation of learning outcomes, and management. The following is an explanation of the application of the learning of English reading skill through elearning at Universitas Terbuka (UT):

A. UT has good instructional material in a form of additional material given at the initiation stage of its e-learning system. Initiation material provides information and guidelines to participants on how to learn independently, where:

a. It provides explicit guidelines on what must and must not be done by elearning participants.

b. It designs dialogue application that encourages participants to exchange ideas, ask questions, and make judgements regarding their focus material.

c. It motivates participants to be interested in the material taught.

d. It uses communicative writing style, like using the first person point of view.

e. It gives clear separation between themes/topics, by explicitly state the topic changes of each unit.

By modular system, all participants must have the required modules so they can learn the content independently. These learning modules have met the eight important components required ina modular system:

a. Through description of instructional material

b. Targeted learning objectives

c. Instructional material benefits and relevance

d. Examples of competencies after completing the module

e. Instructional material

f. Exercises

g. Feedback

h. Method to evaluate the skills learnt

\section{B. Learning Process}

Learning assistance given in the learning process is known as online tutorial. In its online tutorial, UT employs the following components:

a. Student Activity Center: a web-based learning community facilitating students activities in which students can improve their skills, readthe learning material, search for information and many more. b. Intra-Group Interaction: a web-based group discussion forum in which students can interact with each other to discuss learning material given by teachers. Teachers can also join this group to give a brief review on the materials that they have given the students.

c. Students Administration System: a web-based serviceby which students can view information regarding academic status, achievements, and many more.

d. Intensive Assessment: teachers often give away quizes and assignments to strengthen students' comprehension and then test them at the end of each course program. This component should also be aticipated by a web-based distance learning.

e. Digital Library: it provides a lot of literature resources, not only in the form of ebooks, but also audios, images, and other digital collections. This is a supportive component and built in a database.

f. External Online Material: to support learning, students need external reading resources. In this component, teacher and students can have direct interactions in sharing external materials with other students through the web.

The kind of facility provided through online tutorial is facilitated by a tutor, so students can learn independently both individually and in group without direct help from the teacher.Students who face challenges in learning independently are supported by online tutorial. It also fulfills students' need to obtain deeper information regarding the discussion result both from their peer and also form teachers.

In doing so, Universitas Terbuka has all the requirements to open and manage a distance learning program based on the decree of Ministry of National EducationNo. 107/U/Tahun 2001 dated 2 July, which states:

a. A higher education institute must have resources to design, organize, produce, and distribute all instructional material needed to comply with program curriculum.

b. A higher education institute must collaborate with other higher education institutions/agencies in facilitating the development of the program and its instructional material, giving and arranging learning service and assistance, providing library service, implementing practical learning and field experience, and managing distance evaluation of the learning outcomes.

c. A higher education institute must haveresources to regularly upgrade every instructional material which is madein accordance with the development of science, teachnology, and arts. 
d. A higher education institute must have resources to provide facilities for practical learning and or access for students to perform practical learning.

e. A higher education institute must have the permit for opening and managing a study program.

Accordingly, e-learning based education today not only can give greater access to education but also provide affordable and quality higher education.

\section{Procedures in Learning English Reading through E-learning}

By throughly examining the process of reading for comprehension or information, we can recognise that readers have different purposes. There are readers who seek for general idea so they do not have to read in detail, or those who seek a particular part of a text where they do not have to read from the beginning to the end.In reading procedures, readers should avoid redundancy by skipping reading certain words which readers considered have understood.

In relation to the objective of this research, this study examines how the learning of reading teaches students to achieve competencies in learning English reading skill. Accordingly, the following is a deep analysis of the effectiveness of the six activities in the competency-based learning process of English reading skill at UT. The six activities are:

a. Using different types of text enriches students knowledge about text structure, content, dicourse, and accurate reading strategy

The learning for reading skill is a process of developing reading competency by giving various types of texts written by native speakers of English. Each type of text contains different components, such as grammar, cultural content, discourse, rethorical language, or writing strategy. By reading different types of text students can acquire experience, build sensitivity and enhance their skill in anticipating meaning within the texts.

The use of language from different types of text in learning process will build sensitivity and cultural awareness on the appropriate use of language within a context. Murcia $(2001 ; 18)$ told that cultural awareness is not only knowledge about one particular culture, but also a self-adaptationability toward elements of culture in using a language.Therefore, having the knowledge about the culture of native speakers of English does not waranty one is able to communicate appropriately in English.

Murcia's statement shows that knowledge about the culture of a target language is essential to students.However, what more important is students are able to feel the nuance of the meaning through their experience reading the texts which were written by native speakers. This can only be achieved by reading much different types of text.

In addition to the benefits above, learning which provides opportunities to students to read different types of text will enrich their knowledge about various text structures and reading strategies. As Carel (1984), quoted by Williamson (2008; 7), stated that the building of schemata on text structures and reading strategies of foreign language readers can help them understand, retain, and remember information better.

\section{b. Lacking of Attention in Managing Time to Read}

What important in understanding or preparing different types of text and strategies for students is the preparation of some real follow-up reading activities. It means teachers must be able to encourage and convince students to do more readings and use the strategies in understanding texts. In the learning of reading skill at UT, the basic material or elements for developing reading competencies are present. However, the existing learning process and strategies have not been running well.

\section{c. The Creation of Reading Context and Expectation}

Another strategy used by UT in the learning of reading skillis pre-reading activity. It is for building students' concentration and their schemata on a reading topic.Pre-reading is also a step in developing reading competency. By using schemata and creating expectation toward a topic, students will be able to concentrate on comprehending the text. It can help build students' ability in understanding texts more accurately.

Feuerstein and Schcolnik (1980: 99) argued that the teaching of reading will not proceed well if teachers only instruct students to read without creating expectation and activating their schemata toward text at hand. It is these two factors that are essential in reading comprehension.

Another important activity in reading is keeping or retaining information that is obtained during reading. It is unseparable from the rest of reading activities. It starts from building schemata, processing information within text, and retaining that information in memory. The activity of keeping or retaining information is also critical. Without being able to retain information during reading will only make the other reading stages, starting from preparation until during reading that take considerable amount of time, end in vain, lacking the benefits for the readers themselves.

Teachers transfer information from the author's language and situation into students language and 
situation. It can be done by assigning students with tasks to discuss the text content and make notes of the result by using their own language completed with examples of real life events or students own experience.

\section{Evaluation in the Learning of Reading Skill through E-learning}

There are two kinds of evaluations in the learning of reading skill at UT, process evaluation and learning outcomes evaluation. Process evaluation is carried out to examine the students learning activities during the learning process. Evaluation is given on the third, fifth, and seventh week. The objective of this evaluation is to determine students active participation during learning process. While learning outcomes evaluation is undertaken to measure students learning outcomes which are taken from tasks or assignments they do.

Key to successfully learn reading skill is by reading many texts. Therefore, tutors should keep motivating students to do much readings. This can be done by giving well-controlled extra reading tasks or assignments. Teachers/Tutors for reading course should explain in written form the objectives of the learning of language reading to students. They also must describe the benefits and the strategies onhow to achieve it. They also need to inform or prepare references students will need and use in the course.

Tutors should create easeness for students to access appropriate reading resources. For example, by giving them links to external reading material resources and how to access them.

Students must have awareness that their learning success is not only the tutor's responsibility, but also, at most part, is the students own willingness.

Culture findings that are continuously occuring in the learning process show that teachers have new roles in an e-leraning based teaching. These roles include: (1) mastering the ICT and having the ability to handle technical problems on the technology; (2) having the ability to interact with students in written form; (3) becoming a motivator; and (3) giving written feedback to students.

\section{CONCLUSION}

The learning of reading skill at Universitas Terbuka (literally Open University)is generally managed well in improving skill in academic reading that is comprehending English texts within academic environment.The reading skill is achieved through the use of different types of text; implementation of the reading phases, i.e. pre-reading, during-reading, and post-reading which facilitate students with interactive approach.

The successful implementation of an e-learning education is supported with the existence ofmaximum interaction between teacher and students, students and learning facilities, student and student, also the occurence of active learning pattern within the interactions. Some obstacles that hinder students in achieving their reading objective are caused by students' lack of awareness in making their function as the learning subject as much as possible. As the consequences, they have not yet been actively praticipating in online tutorial discussion and in completing tasks given by tutors.

\section{REFERENCES}

Alexander, J. Estill dan Betty S. Heathington. 1988. Assessing and Correcting Classroom Reading Problems. London: Scott, foresman and Company.

Andriani, Durri. 2003. Sistem Pendidikan Jarak Jauh untuk Menciptakan Pendidikan Tinggi Berkualitas; Cakrawala Pendidikan, E-learning dalam Pendidikan. Jakarta: universitas Terbuka.

Brown, H. Douglas. 2005. Principle of Language Learning and Teaching. New York: Longman,

Celce-Murcia. 2001. Teaching English as a Second Foreign Language. USA: Heile \& Heile.

Feuerstein, Tamar dan Miriam schcholnik. 1995. Enhancing Reading Comprehesion in the language learning classroom. California USA: Alta Book.

Flood, James dan Dianne Lapp. 2001. Language Reading Instruction for the Young Child. New York: McMillan Publishing Company.

Mager, R. 1995. Making Instruction Work or Skillbloomers. Kuala Lumpur: Golden Book Centre.

Murphy, Richard A. 2005. From Practice to Performance. Washington DC: the English Language Programs Division of the US Information.

Williams, David. 2003. "Developing Reading Comprehension Skills at the Post-Primary”, English Teaching Forum, Vol. 21 Number 3.

Williamson, Julia. 1988. Improving Reading Comprehension: Some Current Strategies”, English Teaching Forum, Vol. XXVI, Number 1. 